DOI:

UDC 538.911

A. Dedoborez, associate professor, Mathematphysics@gmail.com

A. Kletskov, assistant, alex.k187@i.ua

Department of higher mathematics and physics of the Dnepr state agrarian-economic university

\title{
ANALYSIS OF FASTENING METALS STRUCTURE BY \\ CLUSTER MODEL ON THE BASIS OF RENGENODYFRACTION STUDIES DIAGNOSIS
}

Worked computer program of design cluster structure of fusions to simple metals with a crystalline grate face - centered cube (FCC) and volume cube centred (VCC) of for comparison with experimental data of $x$-ray diffraction analysis.

Keyword: coordinating numbers; optimal clustersize.

Розроблена комп'ютерна програма моделювання кластерної структури розплавів простих металів з кристалічною решіткою гранечентрованою кубічною (ГЦК) та об'ємноцентрованою кубічною (ОЦК) для зіставлення з експериментальними даними рентгенодифракиійного аналізу.

Ключові слова: координаційні числа; оптимальний розмір кластера.

\section{Raising of problem}

High speed the crystallization of metals is one of certificates of presence of well-organized, cluster structure of fusions to simple metals, that predetermines the necessity of interpretation data of neutronandx-ray researches on the basis of cluster model of structure of simple liquids.

\section{Analysis of the last researches and publications}

Neutronandx-ray research of simple liquids and fusions is devote many works, including $[2,3]$. For realization the structural analysis of fusions to simple metals within the framework of cluster model drawn on the results of research of authors $[1,4,5,6,7,8]$.

\section{Formulation of research purpose}

The purpose of work is development of the computer program to design the cluster structure of fusions to simple metals with a crystalline grate face-centered cube (FCC) and cube (CCV) centred by volume of for comparison with experimental data of neutronandx-ray analysis, determination form and basic structural parameters of clusters - mean value of coordinating number, middle atom distance, optimal clustersize.

\section{Exposition of basic material}

Interpretation of these diffraction researches on the basis of cluster model of structure of liquids requires implementation of complex of calculation tasks - from the choice of form of cluster to establishing a connection between the parameters of model and data of diffraction analysis. Corresponding calculations are represented in this work for clusters with the structures of FCC and CCV of grates.

The choice of form to the cluster was determined in accordance with principles of Kuri-Wulfa about a minimum of superficial energy to the crystal, which is in an equilibrium with the liquid and to corresponds principle Gallant according to which a crystal is limited to the atomic planes with the maximal closeness of atoms.

In FCC to the grate such are atomic planes $\{110\}$, from which the built clusters can be in a form: octahedron, tetrahedron, rhombohedron. Thus the first from adopted answers most attitude of volume toward the area of surface, id est is most credible. In CCV to the grate such are atomic planes $\{\overline{1} 0, \overline{1} 0 \overline{1} \overline{1}, 0 \overline{1} \overline{1}, 101,011, \overline{1} 10,1 \overline{1} 0,10 \overline{1}, 01 \overline{1}, 0 \overline{1} 1, \overline{1} 01\}$ from which the built clusters can be in form:bipyramid, prisms, threepyramid. And in this case the first from the adopted clusters answers most attitude of volume toward the area of surface, id est is most credible.

During interpretation of this radial function to distribution of atoms (RFDA) within the framework of cluster model it is necessary to define the methods of calculation of coordinating numbers on a cluster for their next middle on a standard and approximations with experimental RFDA. 
Unlike unfinished ideal to the crystal coordinating number, depends an atom which answers $k-$ to the coordinating sphere on his position, that is why it is necessary to expect the $A V$ coordinating number on a cluster for every coordination. Obviously, that it is possible a next way:

$$
Z_{k}=\sum_{i} N_{k i} Z_{k i} / N(v) \text {, }
$$

where $N_{k i}$ - number of atoms which have a coordinating number, $Z_{k i}$ on every coordinating sphere, $N(v)$ - number of atoms in cluster, when volume have $v$ - atom.

In general case the number of atoms in a cluster is expressed by cube dependence on $v$ :

$$
N(v)=\alpha v^{3}+\beta v^{2}+\gamma v+c,
$$

where $\alpha, \beta, \gamma, c$ is determined for each of forms of clusters. Numbers:

also can be presented by analogical dependence

$$
Q_{k}(v)=\sum Z_{k i} N_{k i}(v)
$$

$$
Q_{k}(v)=Z_{k \infty}\left(\alpha_{k} v^{3}+\beta_{k} v^{2}+\gamma_{k} v+\delta_{k}\right)
$$

But, if in first case, parameters are determined relatively simply, then for being $\alpha_{\kappa}, \beta_{\kappa}, \gamma_{\kappa}, \delta_{\kappa}$ it is necessary to define the value of $Q_{k}(v)$ for the different number of atoms in the rib of cluster $(v)$ for to all coordinating spheres which are used in calculations. For this purpose the algorithm of calculation of them was created by means of computer and after their determination the put task could be untied for all used forms of clusters.

As known, at consideration of diffraction on the limited object in a structural factor it is expedient to use the function of form $V\left(x_{p}\right)$ [1]

$$
a(S)=\sum_{-\infty}^{+\infty} V\left(x_{p}\right) \exp \left(i S x_{p}\right)
$$

where $x_{p}$ is rarius which connects some a central atom is arbitrarily chosen from $P$ - by an atom, $S$ is a factor of dispersion. Function of form

$$
V\left(x_{p}\right)=\frac{1}{N} \sum_{m=-\infty}^{+\infty} \sigma\left(x_{m}\right) \sigma\left(x_{m \pm p}\right),
$$

where $\sigma\left(x_{m \pm p}\right)$ - function of Evald;

$$
\sigma\left(x_{m+p}\right)=\left\{\begin{array}{c}
1, \quad x_{m p} \in V \\
0, x_{m p} \bar{\epsilon} V
\end{array}\right\}
$$

where $V$ is a volume of some limited area.

Discrete forms were found $V\left(x_{p}\right)$ for the areas of different form of structure of FCC for clusters as an octahedron and CCV as bipyramid and them continuous analogues. Also the continuous functions of form are found for all forms of clusters of structure of FCC and CCV. For them does not fold difficulties and being of characters of Fourier, for description of profile of diffraction peaks. For an octahedron general intensity:

\section{bipyramid -}

$$
i(S)=\frac{1}{d} \int_{-L}^{L} V(x) e^{i S_{0} x} d x=3-\cos \alpha-2 \alpha^{2} \sin \alpha,
$$

$$
i(S)=\frac{L}{2 d \alpha^{4}}\left[6 \alpha^{2}-\alpha^{2} \cos \alpha-2(\sin \alpha)^{2}-4 \alpha \sin \alpha-2 \cos \alpha+2\right],
$$

where $\alpha=S \cdot L, d$ is between plane distance, $\mathrm{L}$ is a characteristic clustersize for normals to family of beatings back planes.

The design program was carried out on such chart:

1. Introduction of experimental structural factor of a $(S)$, where $S$ of - the change of wavevector at dispersion. The offered procedure is demonstrated on the example of diffraction researches of a $(S)$ fusion of copper (with the structure of FCC) at $T=$ of 1393K [2] but to fusion to the rubidium (with the structure of $\mathrm{CCV}$ ) at $T=$ of $513 \mathrm{~K}[3]$.

2. A calculation of RFDA is on the type of diffraction peak. The method of apodization [was thus used [4,5], what consists in the conduct of introductionof gravimetric function at being of functions of distribution atoms by the method of regularizationto equalization of Tihonov in the diffraction tasks of research of macroscopically izotropicstructures, which allows considerably to decrease oscillator component, related to the error of measuring and presence of top limit of size of change of wavevector, while in default of gravimetric function procedure of receipt results in blurring of peaks of function of distribution of atoms.

$$
G(r)=(4 \pi \tau)^{-\frac{1}{2}} \int_{-\infty}^{\infty} 4 \pi x \rho(x) \exp \left(-\frac{(r-x)^{2}}{4 \tau}\right) d x=4 \pi r \rho_{0}+\frac{2}{\pi} \int_{0}^{S_{m}} S[a(S)-1] e^{-\tau S^{2}} \sin S r d r,
$$


where $\tau$ - constant of apodization, $\rho(x)$ is a local atomic closeness. Thus

$$
4 \pi r \rho(r)=\sum_{k} \frac{z_{k}}{r_{k \sqrt{2 \pi \sigma^{2}}}} \exp \left(-\frac{\left(r-r_{k}\right)^{2}}{2 \sigma^{2}}\right) \text {. }
$$

In right part of equalization $\mathrm{G}_{\text {експ }}$ can be found minimization of quadratic form

$$
Q=\int_{r_{1}}^{r_{2}}\left\{G(r)-G_{e}(r)\right\}^{2} d r .
$$

3. The system of normal transcendent equalizations, which got untied by the method of the gradient lowering, turned out.

The initial values of parameters of $z_{k} r_{k}, \sigma_{k}$ coming from supposition about the type of near order accordingly position of diffraction peak. $\sigma_{k}$ - on speed of distribution of sound and nearest between atom distances. The weekend of $z_{k}$ was determined by the estimation of middle sizes of efficiency in fusions and on her form. Choosing the that or other form of area of efficiency determine such values her middle sizes, that deviation of theoretical type of diffraction peak from experimental was minimum.

4. A type was approximated by expression

$$
i(S)=\frac{B}{d_{n k 1}} \int_{0}^{\infty} g(L) d L \int_{-L}^{L} V\left(\left|\frac{x}{L}\right|\right) \cos S x d x,
$$

where model function of distribution of clusters for to the sizes

$$
g(L)=A L^{\frac{3 n}{2}} \exp \left(-\beta L^{m}\right)
$$

Coefficient $A$ is determined from the condition of norms setting

$m=2-3$ (best approximation $m=3, n=1$ ).

$$
\int_{0}^{\infty} g(L) d L=1
$$

Minimization (9) is determine $z_{k}, r_{k}, \sigma_{k}$ are the specified values for 30 coordinating spheres.

5. The result of approximation is determination of mean value of coordinating number, middle between atom distance, optimal clustersize.

The worked out program of design allows to conduct research of changes of structural parameters in the wide interval of temperatures.

So in works on research of physical properties $[6,7,8]$ it was shown that the change of structure of near coordination in fusions of alkaline metals $(\mathrm{Rb}, \mathrm{Cs})$ with a temperature takes place not droningly, but place is taken saltatory at certain temperatures or in the very narrow interval of temperatures.

These changes correlate with the anomalous phenomena on dependences of viscidity and closeness on a temperature. Yes, for fusions of rubidium it takes place in the interval of temperatures $250^{\circ}-300^{\circ} \mathrm{C}$.

In this work research of temperature dependences of parameters of structure of fusions of rubidium is conducted in the interval of temperatures from near to the melting-point $-40^{\circ} \mathrm{C}$ $\left(t^{\circ}{ }_{\text {mel }}=38,9^{\circ} \mathrm{C}\right)$, to $400^{\circ} \mathrm{C}$. Data of diffraction researches were used for the brought object [over 3]. For a design the form of cluster was used as bipyramid. The mean values of between atom distance, optimal clustersizes, middle distances, were determined between clusters.

In the interval of temperatures $250^{\circ}-300^{\circ} \mathrm{C}$ was observed saltatory changes of afore-named parameters. The special attention is deserved by dependence of optimal clustersize $\left(L_{\text {opt }}\right)$ on a temperature $(T)$ which with high exactness of approximation answers dependence $-L_{o p t}=\operatorname{Aexp}\left(\frac{\Delta E}{R T}\right)$

Energy of activating $\Delta E$ it follows to interpret with the increase of the combined superficial energy of clusters the sizes of which diminish with the increase of temperature. In the afore-named interval of temperatures there was a change $\Delta E$ from $1,537 \frac{\mathrm{kJ}}{\mathrm{mol}}$ in the interval of temperatures $40^{\circ}$ $240^{\circ} \mathrm{C}$, to $2,493 \frac{\mathrm{kJ}}{\mathrm{mol}}$ in the interval of temperatures $300^{\circ}-400^{\circ} \mathrm{C}$. It is the certificate of phase transition of II of family, which can be bound to the change of form to the cluster, for example, of passing to the varieties of prism, biprisms which are answered by less attitude of volume toward the area of surface, id est substantially greater superficial energy. But it requires the detailed analysis: implementation of design for the different forms of clusters, peculiar to the structure of FCC in different temperature intervals. In addition, extrapolation of dependence of $L_{\mathrm{opt}}(T)$ pithily melting gives a value medium-sized of cluster over 14 angstrom for the considered case of bipyramid. If to interpret the 
warmth of crystallization $-2,31 \frac{\mathrm{kJ}}{\mathrm{mol}}$ as the disengaged combined superficial energy of clusters, there is possibility to find her dependence on the sizes of clusters and from a temperature, and, finally, to estimate the size of between atom potential which is a separate task.

These changes correlate with the anomalous phenomena on dependences of viscidity and closeness on a temperature. Yes, for fusions of rubidium it takes place in the interval of temperatures $250^{\circ}-300^{\circ} \mathrm{C}$.

\section{Conclusions}

The worked out computer program provided exactness of approximation of $0,05 \%$. For the brought objects [over 2] it is got: $A V$ between atom distance $-6,677 \AA$, optimal clustersize $-18,597 \AA$, $A V$ coordinating number $-0,962, A V$ distance between clusters $-0,474 \AA$, for objects [3] it is got: $A V$ between atom distance $-5,755 \AA$, optimal clustersize $-12,756 \AA, A V$ coordinating number $-1,325$, $A V$ distance between clusters $-0,518 \AA$. research of temperature dependences of parameters of structure of fusions of rubidium is Conducted in the interval of temperatures from near to the melting-point $-40^{\circ} \mathrm{C}\left(t^{\circ}{ }_{\mathrm{mel}}=38,9^{\circ} \mathrm{C}\right)$, to $400^{\circ} \mathrm{C}$.

\section{References}

[1] Hinie A. (1961) Rentehenografiia kristalov. Teoriia i praktika. [Rentgenografic of crystals. Theory and practice] Moskva. (in Russian)

[2] ElderO.Y., EtpresserE., Kunsch B., Stiller H. and Suda M. (1980).The Structure factor of liquid copper at 1393 K, 1833K. - J. Phys.F. Metall Phys. Vol 10. 183p. (in English)

[3] Waseda Y. and Suzuki K. (1972). Physics state solid. (B). Vol.49. 643p. (in English)

[4] Gulivets N.I., Bobyl A.V., Dedoborets A.Y., Peleshenko B.I. (1997) Funktsiia raspredeleniia atomov makroskopicheski izotropnykh obektov $\mathrm{v}$ difraktsionnykh issledovaniiakh []. Pisma $\mathrm{v}$ ZhTF - Letters to Jornal of theoretic Physics, 23(5), 21-26.

[5] Tikhonov A.N., Arsenin V.Ya. (1979) Metody recheniia nekorektnikh zadach [] Moskva: Nauka (in Russian)

[6] Gingrich N.S., Heaton L.P., J. Chem. (1961)Physics. Vol. 34. 873 p. (in English)

[7] Black R., Suck J.B., Glaser W. et al (1976) Ber. Bunsen-Gesellschaft. Bd. 80.8.- S. 718 (in Germany)

[8] Zei M.S. (1983) Rhys. Rev. A. Vol. 27. Numb. 1. 515 p. (in English)

\section{АНАЛІЗ СТРУКТУРИ РОЗПЛАВІВ ПРОСТИХ МЕТАЛІВ У РАМКАХ КЛАСТЕРНОЇ МОДЕЛІ НА ОСНОВІ ДАНИХ РЕНТГЕНОДИФРАКЦЙНИХ ДОСЛІДЖЕНЬ \\ Дідоборець О.Й., Клєцков О.М.}

\section{Реферат}

Метою роботи є розробка комп'ютерної програми моделювання кластерної структури розплавів простих металів з кристалічною решіткою гранецентрованою кубічною (ГЦК) та об’ємно центрованою кубічною для зіставлення з експериментальними даними рентгенодифракційного аналізу.

Розрахунок координаційних чисел по кластеру для їх наступного усереднювання за зразком і зіставлення (апроксимації) з експериментальною радіальною функцією розподілу атомів (РФРА). При цьому вибір форми кластера здійснювався відповідно до принципу Кюрі-Вульфа та Браве - про мінімум поверхневої енергії кристала, який знаходиться в рівновазі зі своєю рідиною, і тим, що кристал обмежується атомними площинами 3 максимальною щільністю атомів. Для ГЦК грат їм відповідають кластери у формі: октаедра, тетраедра, ромбоедра, причому першою з названих відповідає найбільше відношення об'єму до площі поверхні, тобто вона є найбільш достовірною. 
Для вказаних вище форм кластерів були визначені дискретні функції форми і їх безперервні аналоги у різних напрямах трансляцій.

По отриманих функціях були певні Фур'є-образи (інтенсивності) для опису профілів дифракційних піків для випадку октаедра. Використанням отриманих залежностей розроблена комп'ютерна програма моделювання кластерної структури, яка полягала в апроксимації експериментальних даних рентгенодифракційних досліджень розплавів міді теоретичною моделлю. Результатами апроксимації є: визначення середнього значення координаційного числа, середньої міжатомної відстані, оптимального розміру кластера, середньої відстані між кластерами. Отримані дані для міді при температурі $1393 \mathrm{~K}$ мають наступні значення: середня міжатомна відстань $6,677 \AA$, оптимальний розмір кластера $-18,597 \AA$, середнє координаційне число $-0,962$, середня відстань між кластерами - $0,474 \AA$.

Дані для рубідія при температурі $1393 \mathrm{~K}$ мають наступні значення: середня міжатомна відстань $-5,755 \AA$, оптимальний розмір кластера $-12,756 \AA$, середнє координаційне число 1,325 , середня відстань між кластерами $-0,518$ А.

\section{Література}

1. Гинье А. Рентгенография кристаллов. Теория и практика: монография. М.: Изд. Наука. 1961. $500 \mathrm{c}$.

2. Elder O.Y., Etpresser E., Kunsch B., Stiller H. and Suda M. The Structure factor of liquid copper at 1393 K, 1833K. Journal of Physics.F. Metall Physics. 1980. Vol 10. 183p.

3. Waseda Y. and Suzuki K. Physics solid state. 1972.Vol.49(B). 643p.

4. Гуливец Н.И., А.В. Бобыль, А.И.Дедоборец, Б.И.Пелешенко. Функция распределения атомов макроскопически изотропных объектов в дифракционных исследованиях. Письма в ЖТФ. 1997. № 23(5). С.21-26.

5. Тихонов А.Н., Арсенин В.Я. Методы решения некорректных задач. М.:Изд. Наука. 1979. $288 \mathrm{c}$.

6. Gingrich N.S., Heaton L.P. Journal of Chemical Physics. 1961. Vol. 34. 873p.

7. Black R., Suck J.B., Glaser W. Journal Berlin Bunsen-Gesellschaft. 1976. №. 80.8. p.718

8. Zei M.S. Physics Review American. 1983.Vol. 27. №. 1. 515 p. 